\title{
Resistance in Strawberry Isolates of Colletotrichum acutatum from Florida to Quinone-Outside Inhibitor Fungicides
}

Bruna B. Forcelini and Teresa E. Seijo, Gulf Coast Research and Education Center, University of Florida, Wimauma 33598; Achour Amiri, Tree Fruit Research and Extension Center, Washington State University, Wenatchee 98801; and Natalia A. Peres, Gulf Coast Research and Education Center, University of Florida

\begin{abstract}
Forcelini, B. B., Seijo, T. E., Amiri A., and Peres, N. A. 2016. Resistance in strawberry isolates of Colletotrichum acutatum from Florida to quinoneoutside inhibitor fungicides. Plant Dis. 100:2050-2056.

Anthracnose fruit rot of strawberry, caused by Colletotrichum acutatum, is a major disease in Florida and frequent quinone-outside inhibitor (QoI) fungicide applications are needed for disease control. From 1994 to 2014, 181 C. acutatum isolates were collected from multiple strawberry fields in Florida with or without QoI spray history. Sensitivity to azoxystrobin and pyraclostrobin was tested based upon mycelial growth and germ tube elongation inhibition. Mean effective concentration where growth was reduced by $50 \%\left(\mathrm{EC}_{50}\right)$ values for isolates collected prior to 2013 based upon mycelial growth were 0.22 and $0.013 \mu \mathrm{g} / \mathrm{ml}$ and upon germ tube elongation were 0.57 and $0.03 \mu \mathrm{g} / \mathrm{ml}$ for azoxystrobin and pyraclostrobin,

respectively. Mycelial growth and germ tube elongation of 48 isolates collected in 2013 and 2014 were not inhibited with azoxystrobin at $3 \mu \mathrm{g} / \mathrm{ml}$ and pyraclostrobin at $0.110 \mu \mathrm{g} / \mathrm{ml}$. A fungicide discriminatory dose assay indicated that 43 of the 48 isolates had $\mathrm{EC}_{50}$ values higher than 100 and $10 \mu \mathrm{g} / \mathrm{ml}$ for azoxystrobin and pyraclostrobin, respectively. Azoxystrobin and pyraclostrobin sprayed preventively on strawberry fruit inoculated with $C$. acutatum failed to control resistant isolates. Sequencing of the cytochrome $b$ gene of sensitive and resistant isolates showed that QoI-resistant isolates contained either G143A or F129L amino acid substitutions.
\end{abstract}

Anthracnose fruit rot (AFR) and anthracnose root and crown necrosis (ARN), caused by Colletotrichum acutatum J. H. Simmonds, are major diseases of strawberry (Fragaria $\times$ ananassa) in Florida and in the southeastern United States, where weather conditions are favorable for disease development (Legard et al. 2003; Maas 1998; Mertely and Peres 2012a). Flower blight and fruit rot are the main symptoms of AFR (Maas 1998; Peres et al. 2005). However, when transplants are infected in the nursery, root and crown necrosis can occur (Peres and MacKenzie 2013; Peres et al. 2005).

Strawberry is cultivated as an annual crop in Florida and C. acutatum does not oversummer in the soil (Ureña-Padilla et al. 2001). The source of primary inoculum is nursery transplants carrying quiescent infections (Howard et al. 1992). After plant establishment, under long wetness periods and temperatures above $20^{\circ} \mathrm{C}$, secondary conidia are produced and become the source of inoculum for flower and fruit infections (Leandro et al. 2001; Maas 1998; Mertely and Peres 2012a; Peres et al. 2005). Characteristic AFR symptoms on infected fruit are dark, sunken lesions with orange mucilage containing conidia. C. acutatum has been shown to successfully infect fruit at all maturity stages; however, red mature fruit are most susceptible (Mertely and Peres 2012a; Wilson et al. 1990). Strawberry flowers are also extremely susceptible to $C$. acutatum and the main symptom of AFR consists of brown lesions on infected petals (Mertely and Peres 2012a). Under severe epidemics, C. acutatum can cause root necrosis. Not much information is available about the spread of inoculum from aboveground strawberry tissue to the roots. However, it has been suggested that roots may become contaminated by farming operations during digging of transplants and packing in nurseries (Mertely and Peres 2012b; Peres et al. 2005; Ureña-Padilla et al. 2001). After plant establishment, when overhead irrigation is withdrawn, strawberry transplants with $C$. acutatum-infected roots fail to establish and collapse. Infected young roots display brown lesions, whereas

Corresponding author: N. A. Peres; E-mail: nperes@ufl.edu

Accepted for publication 6 May 2016.

http://dx.doi.org/10.1094/PDIS-01-16-0118-RE

(C) 2016 The American Phytopathological Society older roots are brown or black and decayed (Freeman and Katan 1997; Mertely and Peres 2012b).

The use of disease-free transplants is the most important control method to prevent AFR and ARN disease outbreaks in production fields (Mertely and Peres 2012a,b; Peres 2015). ARN control starts prior to planting. Some growers in Florida treat bareroot transplants by dipping them in suspensions of single-site mode-of-action fungicides to kill inoculum present on root and crown tissue (Daugovish et al. 2009; Mertely and Peres 2012b; Mertely et al. 2010). After plant establishment, when weather conditions are less favorable for $C$. acutatum development, low label rates of multisite modeof-action fungicides such as Captan are recommended to prevent AFR (Mertely and Peres 2012a). Because petioles and leaves may also harbor $C$. acutatum inoculum, these frequent applications of multisite fungicides are essential to prevent AFR outbreaks when strawberry flowers and fruit are developing. Rates and frequencies of application of these compounds increase toward the end of the season, when inoculum builds up and plants are exposed to prolonged wetness periods and high temperatures (Maas 1998; MacKenzie and Peres 2012; Wilson et al. 1990). When AFR symptoms are present, single-site fungicides such as azoxystrobin and pyraclostrobin are recommended as tank mixtures with multisite fungicides (Mertely and Peres 2012a; Turechek et al. 2006).

Respiration-inhibitor (RI) fungicides such as the quinone-outside inhibitors (QoI) are the most commonly used single-site fungicides for control of anthracnose (Mertely and Peres 2012a,b; Turechek et al. 2006). One of the most common groups within the QoI are the strobilurin fungicides, and two of its active ingredients (a.i.), azoxystrobin and pyraclostrobin, have been used intensely on strawberry since their release (Bartlett et al. 2002; Mertely and Peres 2012a). These compounds inhibit ATP production during mitochondrial respiration by binding to the Qo center on the cytochrome $b$ (cytb) gene (Bartlett et al. 2002; Sauter et al. 1999; Ypema and Gold 1999). Some fungi have been shown to develop an alternative respiration pathway in vitro and are able to grow on amended media. This alternative pathway can result in false positive resistant isolates. Consequently, salicylhydroxamic acid (SHAM) is incorporated into the medium when testing QoI fungicides in in vitro assays because it blocks the alternative respiration pathway (Wood and Hollomon 2003). The addition of SHAM to azoxystrobin-amended media 
increased mycelial growth and respiration inhibition of Sclerotinia sclerotiorum compared with when azoxystrobin was used alone (Duan et al. 2012). However, in vitro studies evaluating sensitivity of C. acutatum of citrus (Mondal et al. 2005) and C. graminicola of turf (Avila-Adame et al. 2003) to RI fungicides have shown that SHAM did not increase mycelial inhibition and suggests that these pathogens do not utilize an alternative respiration pathway. Currently, no information is available on the effects of SHAM on $C$. acutatum mycelial growth and respiration inhibition when conducting in vitro testes with RI fungicides.

QoI fungicides have been categorized as code group 11 by the Fungicide Resistance Action Committee (FRAC 2016), which has a high risk of resistance development. Numerous applications of QoI fungicides can lead to selection of isolates resistant to these products. QoI resistance has already been reported in many pathogens such as C. graminicola in turf (Avila-Adame et al. 2003), Venturia inaequalis on apple (Lesniak et al. 2011), Podosphaera fusca (synonym P. xanthii) and Pseudoperonospora cubensis on cucumber (Ishii et al. 2001), Botrytis cinerea on strawberry (Amiri et al. 2013), and different Alternaria spp. on pistachio (Ma et al. 2003). However, QoI resistance has not yet been reported in C. acutatum isolates from strawberry despite frequent use or, to the best of our knowledge, in C. acutatum affecting any other crop (Peres et al. 2009).

Resistance to QoI fungicides can occur as a result of point mutations in the cytb gene. Three amino acid substitutions (i.e., G143A, F129L, and G137A) have been reported to confer different levels of QoI resistance (Gisi et al. 2002; Sierotzki et al. 2007). The G143A mutation results in the substitution of glycine (G) by alanine (A) at position 143. This mutation confers a high level of resistance and is the most commonly found in resistant isolates (Gisi et al. 2002). When the G143A mutation is present, disease control usually fails even at high fungicide rates. The two other mutations, a replacement of phenylalanine $(\mathrm{F})$ by leucine (L) at position 129 (F129L) and a substitution of glycine by arginine at position 137 (G137R), are linked with moderate levels of resistance (Bartlett et al. 2002; Pasche et al. 2004; Sierotzki et al. 2007). Fungal isolates with these mutations are usually controlled when exposed to field rates of QoI fungicides.

During the 2013-14 Florida strawberry season, growers experienced anthracnose control failure after treating transplants with QoI fungicides before planting. C. acutatum was isolated from plants with root and crown rot. The objectives of this study were to (i) determine the sensitivity to azoxystrobin and pyraclostrobin of $C$. acutatum isolates collected from Florida strawberry fields in a 20-year period, (ii) evaluate the efficacy of azoxystrobin and pyraclostrobin field rates to control recently collected $C$. acutatum isolates, and (iii) characterize the molecular mechanism of resistance in QoI-resistant isolates.

\section{Materials and Methods}

Collection, isolation, and storage of $C$. acutatum isolates. In total, 181 C. acutatum isolates (Table 1) were collected from 1994 to 2014 from anthracnose-affected strawberry plants from commercial fields (148 isolates) in Florida and the research fields (33 isolates) of the University of Florida Institute of Food and Agricultural Sciences Gulf Coast Research and Education Center (GCREC; Dover and Balm, FL). Isolates were collected by harvesting spores directly from sporulating lesions or from tissues surface disinfested with ethanol and sodium hypochlorite, and plated on potato dextrose agar (PDA) medium amended with streptomycin at $0.1 \mathrm{~g} / \mathrm{liter}$ and ampicillin at $0.25 \mathrm{~g} /$ liter. C. acutatum isolates identified by cultural morphology and conidial shape and size were single spored on PDA and stored dry on filter paper at $-20^{\circ} \mathrm{C}$ or in glycerol at $-80^{\circ} \mathrm{C}$. In all, 23 isolates collected from 1994 to 1999 that had not been exposed to QoI fungicides formed the baseline population. The other 154 isolates collected after the commercial release of QoI products represented the QoI-sprayed population.

Fungicides. The commercial formulations of azoxsytrobin (Abound 2.08F, 22.4\% a.i.; Syngenta Crop Protection) and pyraclostrobin (Cabrio EC, $20 \%$ a.i.; BASF) were used for fungicide sensitivity evaluations. Fungicides were diluted in sterile deionized water to prepare stock suspensions of a.i. at 388.4 and $14.23 \mu \mathrm{g} / \mathrm{ml}$ for azoxystrobin and pyraclostrobin, respectively. For azoxystrobin, the concentrations evaluated ranged from 0.01 to $3 \mu \mathrm{g} / \mathrm{ml}$ and for pyraclostrobin from 0.001 to $0.110 \mu \mathrm{g} / \mathrm{ml}$. For additional trials, increased concentrations of azoxystrobin (1 to $100 \mu \mathrm{g} / \mathrm{ml})$ and pyraclostrobin $(0.110$ to $10 \mu \mathrm{g} / \mathrm{ml})$ were used to test mycelial growth inhibition of seven $C$. acutatum isolates. SHAM at $100 \mu \mathrm{g} / \mathrm{ml}$ was added to QoI-amended PDA to evaluate sensitivity of mycelium, spore, and germ tube.

Fungicide sensitivity evaluation. Mycelium growth and germ tube elongation were evaluated to determine $C$. acutatum sensitivity to QoI fungicides using the spiral gradient dilution method previously described by Förster et al. (2004).

Mycelium growth. For isolates collected between 1994 and 2011, cellophane strips were used to seed the medium (Förster et al. 2004) whereas, for isolates from 2013 and 2014, PDA + agar (PDAA) strips were used according to Amiri et al. (2013). Medium (50 ml) containing $39 \mathrm{~g}$ of PDA amended with $5 \mathrm{~g}$ of agar per liter to harden the medium was poured into 150 -mm-diameter petri dishes to produce strips. Seeding of the medium with fungal isolates and cutting of the strips followed the method described by Amiri et al. (2013).

Each fungicide suspension $(50 \mu \mathrm{l})$ was applied in a continuous spiral concentration gradient to the surface of $150-\mathrm{mm}$ plates with PDA using an Autoplate 4000 (Spiral Biotech, Inc.). Plates were incubated for 2 to $4 \mathrm{~h}$ at room temperature to allow fungicide to diffuse through the agar. Fungicide-amended plates were seeded across the fungicide concentration gradient with cellophane or PDAA strips covered with mycelium. Strips of each isolate were applied in duplicate and two isolates were tested per plate. Of the 181 isolates, 12 (1 baseline and 11 QoI-sprayed isolates) were tested in SHAM-amended medium. Three replicate petri dishes were seeded for each isolate-fungicide combination and control (PDA) and then incubated at $24^{\circ} \mathrm{C}$ under constant light. Mycelium growth was measured after $72 \mathrm{~h}$. The point within the fungicide gradient where mycelial growth was reduced by $50 \%$ as compared with control plates $(50 \%$ effective concentration $\left[\mathrm{EC}_{50}\right]$ ) was marked and distance to the plate center was used to determine the $\mathrm{EC}_{50}$ values using the Spiral Gradient Endpoint Software (Spiral Biotech, Inc.). Each experiment was conducted twice.

Mycelial growth of 54 of the 181 isolates was also tested using discriminatory doses of azoxystrobin and pyraclostrobin. One 6-mm-diameter plug from the edge of 7-day-old colonies from each isolate was transferred to $60-\mathrm{mm}$ petri dishes containing PDA (control), PDA + azoxystrobin $(100 \mu \mathrm{g} / \mathrm{ml})$, or PDA + pyraclostrobin (10 $\mu \mathrm{g} / \mathrm{ml})$. Mycelial growth was measured after 3 days of incubation at $24^{\circ} \mathrm{C}$. Three plates per fungicide-isolate and two for control-isolate combinations were used. The experiment was repeated once.

Conidial germination. Three baseline isolates 95-61C, 96-90, and 96-95 were selected to evaluate the effect of azoxystrobin on spore germination. Conidial suspensions containing 100 spores were seeded to PDA plates amended with azoxystrobin at $0,0.01,0.1,1,10$, or $100 \mu \mathrm{g} / \mathrm{ml}$ with or without SHAM. Three 150 -mm-diameter petri dishes were seeded for each isolate-fungicide concentration and germinated conidia were determined by the number of single colonies after 2 to 3 days of incubation at $24^{\circ} \mathrm{C}$.

Germ tube elongation. Germ tube elongation sensitivity to azoxystrobin and pyraclostrobin was also tested for 1 baseline isolate (95-61C) and 11 QoI-exposed isolates using the spiral gradient dilution method. After plates were divided into six sections, $7 \mu l$ of a $10^{3}$ conidia/ml suspension was seeded in duplicate across the concentration gradient with a multichannel pipette. Three isolates were evaluated per plate and two replicate plates were used for each fungicide, fungicide + SHAM, or control. Plates were incubated at room temperature (approximately $23^{\circ} \mathrm{C}$ ) and germ tube elongation was evaluated microscopically. The germ tube length of 10 spores/ replicate of each of the three control plates was measured and averaged. The $\mathrm{EC}_{50}$ value was determined at the fungicide gradient point where most of the germinated spores had germ tubes that measured half the length of the average germ tube on the control plates. 
Inoculum preparation. Isolates were transferred from glycerol or filter paper to $100-\mathrm{mm}$-diameter plates containing PDA, and grown for 4 to 7 days at $24^{\circ} \mathrm{C}$ under constant light. Conidia were harvested by flooding plates with sterile deionized water and scraping the fungal colonies with a glass rod. Conidial suspensions were then filtered through a sterile double layer of cheesecloth and adjusted to $10^{6}$ conidia/ml with a hemocytometer. Suspensions were prepared the day of the experiment and kept at $4^{\circ} \mathrm{C}$.

Fruit assay. The efficacy of the commercial formulations of azoxystrobin and pyraclostrobin to control sensitive and resistant isolates on strawberry fruit was tested. Four resistant and eight sensitive isolates were selected. Three of the eight sensitive isolates were chromogenic and produced dark purple fungal colonies. Immature fruit of 'Strawberry Festival' that had receptacles with chlorophyll were harvested from experimental plots at the GCREC. In the laboratory, fruit were selected for uniformity and surface disinfested in $0.7 \%$ sodium hypochlorite for $6 \mathrm{~min}$, then rinsed twice with sterile deionized water. Four fruit per isolate were placed in egg cartons inside clean plastic boxes according to replication and treatment and were surface dried inside the hood for $20 \mathrm{~min}$. To maintain humidity inside the boxes, $100 \mathrm{ml}$ of deionized water was placed under the egg cartons.

Fruit were sprayed with field rates of Abound $(1.24 \mu \mathrm{g} / \mathrm{ml})$ or Cabrio $(0.001 \mu \mathrm{g} / \mathrm{ml})$ using a spray bottle. Control fruit were sprayed with autoclaved deionized water. Fruit were incubated in closed boxes at room temperature for $24 \mathrm{~h}$ before inoculation. Two sets of isolates (95-61, 13-73, 13-459, 13-483, 14-57, and 14-58; and 3-2,
8-11, 13-10,13-139, 13-486, and 13-488) were tested on two different dates. A $5-\mu l$ droplet of a $10^{6}$ conidia/ml suspension of each C. acutatum isolate was placed on the upper part of each fruit. Fruit were incubated in closed boxes at room temperature for 5 more days and then assessed for AFR incidence and severity. Disease incidence was estimated as the percentage of infected fruit and disease severity as the percentage of fruit area with AFR symptoms. Four replicates of four fruit per isolate were used for each fungicide treatment. Seventytwo fruit were sprayed with water only as controls to determine whether the fruit were infected prior to this test. The experiment was repeated once.

Analysis of $c y t b$ gene sequences from sensitive and resistant C. acutatum isolates. Fungal colonies of 11 QoI-resistant and 7 QoI-sensitive $C$. acutatum isolates were grown on PDA media for 7 days. Mycelia were then harvested and DNA was extracted using the FastDNA Kit (MP Biomedicals). Highly conserved regions of the cytb gene of $C$. graminicola (GenBank accession number AY285743.1) were used to design primers C.gramcytb-bf1 5'-GAAGAGGTATGTAC TACGGTTCATATAG-3' and C.gramcytb-br1 5'-TAGCAGCTGGAG TTTGCATAG-3' using Primer3Plus (http://primer3plus.com). Polymerase chain reaction (PCR) amplification was performed using the following reaction conditions: initial DNA denaturation at $95^{\circ} \mathrm{C}$ for $3 \mathrm{~min}$; followed by 34 cycles of denaturation $95^{\circ} \mathrm{C}$ for $40 \mathrm{~s}$, annealing at $60^{\circ} \mathrm{C}$ for $50 \mathrm{~s}$, and extension at $72^{\circ} \mathrm{C}$ for $1 \mathrm{~min}$; and final extension at $72^{\circ} \mathrm{C}$ for $5 \mathrm{~min}$. Amplification products were assessed by electrophoresis in a $1 \%$ agarose gel with $1 \mathrm{X}$ TAE buffer (0.04 M Tris-acetate,

Table 1. Season, tissue of isolation, number of isolates tested, and effective concentration where growth was reduced by $50 \%$ ( $\mathrm{EC}_{50}$ ) values for sensitive Colletotrichum acutatum isolates from strawberry used in this study

\begin{tabular}{|c|c|c|c|c|c|c|}
\hline \multirow[b]{2}{*}{ Season } & \multirow[b]{2}{*}{ Tissue } & \multirow[b]{2}{*}{ Tested $^{\mathbf{b}}$} & \multicolumn{2}{|c|}{ Mean $\operatorname{EC}_{50}(\mu \mathrm{g} / \mathrm{ml})^{a}$} & \multirow[b]{2}{*}{ Sensitive $^{c}$} & \multirow[b]{2}{*}{ Resistant $^{\mathrm{d}}$} \\
\hline & & & $\overline{\text { Azoxystrobin }}$ & $\overline{\text { Pyraclostrobin }}$ & & \\
\hline 1994-95 & Fruit & 2 & 0.220 & 0.015 & 2 & 0 \\
\hline $1995-96$ & Fruit & 4 & 0.588 & 0.035 & 4 & 0 \\
\hline \multirow[t]{2}{*}{$1996-97$} & Crown & 1 & 0.467 & 0.024 & 1 & 0 \\
\hline & Fruit & 3 & 0.299 & 0.012 & 3 & 0 \\
\hline \multirow[t]{4}{*}{$1997-98$} & Crown & 2 & 0.799 & 0.026 & 2 & 0 \\
\hline & Fruit & 1 & 0.417 & 0.027 & 2 & 0 \\
\hline & Petiole & 3 & 0.174 & 0.013 & 3 & 0 \\
\hline & Unknown & 2 & 0.332 & 0.010 & 2 & 0 \\
\hline \multirow{3}{*}{ 1998-99 } & Crown & 2 & 0.162 & 0.023 & 2 & 0 \\
\hline & Fruit & 1 & 0.126 & 0.011 & 1 & 0 \\
\hline & Petiole & 2 & 0.156 & 0.012 & 2 & 0 \\
\hline \multirow[t]{4}{*}{$2001-02$} & Crown & 2 & 0.131 & 0.007 & 2 & 0 \\
\hline & Fruit & 2 & 0.113 & 0.005 & 2 & 0 \\
\hline & Petiole & 1 & 0.093 & 0.004 & 1 & 0 \\
\hline & Root & 6 & 0.104 & 0.005 & 6 & 0 \\
\hline \multirow[t]{5}{*}{$2002-03$} & Crown & 6 & 0.142 & 0.011 & 6 & 0 \\
\hline & Fruit & 1 & 0.220 & 0.009 & 1 & 0 \\
\hline & Leaf bud & 1 & 0.330 & 0.010 & 1 & 0 \\
\hline & Petiole & 3 & 0.252 & 0.010 & 3 & 0 \\
\hline & Root & 1 & 0.245 & 0.011 & 1 & 0 \\
\hline \multirow[t]{2}{*}{ 2003-04 } & Crown & 8 & 0.145 & 0.011 & 8 & 0 \\
\hline & Petiole & 1 & 0.112 & 0.012 & 1 & 0 \\
\hline 2006-07 & Fruit & 10 & 0.151 & 0.013 & 10 & 0 \\
\hline $2007-08$ & Fruit & 20 & 0.121 & 0.016 & 20 & 0 \\
\hline $2009-10$ & Fruit & 17 & 0.051 & 0.010 & 17 & 0 \\
\hline $2010-11$ & Fruit & 22 & 0.277 & 0.007 & 22 & 0 \\
\hline $2012-13$ & Fruit & 10 & 0.635 & 0.055 & 3 & 7 \\
\hline \multirow[t]{4}{*}{ 2013-14 } & Crown & 11 & - & - & 0 & 11 \\
\hline & Fruit & 9 & - & - & 0 & 9 \\
\hline & Petiole & 1 & 0.055 & 0.042 & 1 & 0 \\
\hline & Root & 19 & 0.473 & 0.047 & 5 & 14 \\
\hline \multirow[t]{2}{*}{ 2014-15 } & Fruit & 4 & - & - & 0 & 4 \\
\hline & Root & 3 & - & - & 0 & 3 \\
\hline
\end{tabular}

\footnotetext{
${ }^{\mathrm{a}}$ Mean $\mathrm{EC}_{50}$ values are based on mycelial growth assay; - indicates that isolates were not inhibited with azoxystrobin and pyraclostrobin at 3 and $0.110 \mu \mathrm{g} / \mathrm{ml}$, respectively.

${ }^{b}$ Number of isolates tested.

${ }^{\mathrm{c}}$ Number of sensitive isolates.

d Number of resistant isolates.
} 
$0.0001 \mathrm{M}$ EDTA buffer) $+2.5 \mu$ l of ethidium bromide. PCR products were purified according to the USB ExoSAP-IT PCR Product Cleanup Product (Affymetrix) instructions, then sequenced by Genewiz Inc. Alignment of sequences was conducted using the BioEdit program (http://www.mbio.ncsu.edu/bioedit/bioedit.html).

Data analysis. Analysis of variance (ANOVA) using PROC GLM was conducted to test the effects of treatments and repetitions within experiments. Data from mycelial growth and germ tube elongation assays were combined after ANOVA determined no significant differences. All statistical analysis were conducted using the SAS software (version 9.4; SAS Institute Inc.).

\section{Results}

Fungicide sensitivity assay. Mycelial growth. $\mathrm{EC}_{50}$ values for the mycelial growth assay were not significantly different between repetitions for azoxystrobin $(P=0.1183)$ and pyraclostrobin $(P=$ 0.8125). Three QoI sensitivity levels were observed among the 181 C. acutatum isolates. Average $\mathrm{EC}_{50}$ values for isolates collected between 1994 and 2011 was $0.22 \mu \mathrm{g} / \mathrm{ml}$ for azoxystrobin and 0.012 $\mu \mathrm{g} / \mathrm{ml}$ for pyraclostrobin (Table 1). For isolates collected from 1994 to 1999, prior to the registration of azoxystrobin, the average $\mathrm{EC}_{50}$ value was $0.30 \mu \mathrm{g} / \mathrm{ml}$. For those collected after azoxystrobin registration until 2011, the mean $\mathrm{EC}_{50}$ value was $0.15 \mu \mathrm{g} / \mathrm{ml}$. Average $\mathrm{EC}_{50}$ values for pyraclostrobin were 0.014 and $0.011 \mu \mathrm{g} / \mathrm{ml}$ for isolates collected before 2000 and 2011, respectively (Table 1). For isolates collected in 2013 and 2014, 10 isolates had $\mathrm{EC}_{50}$ values that ranged from 0.055 to $1.625 \mu \mathrm{g} / \mathrm{ml}$ and from 0.017 to $0.092 \mu \mathrm{g} / \mathrm{ml}$ for azoxystrobin and pyraclostrobin, respectively, and were considered sensitive. For the other 48 isolates collected after 2012, azoxystrobin and pyraclostrobin concentrations of 3 and $0.110 \mu \mathrm{g} / \mathrm{ml}$, respectively, were not sufficient to inhibit mycelial growth (Table 1). Average $\mathrm{EC}_{50}$ values for the seven isolates exposed to concentrations of azoxystrobin and pyraclostrobin at 1 to 100 and 0.110 to $10 \mu \mathrm{g} / \mathrm{ml}$, respectively, was $28.38 \mu \mathrm{g} / \mathrm{ml}$ (azoxystrobin) and $1.43 \mu \mathrm{g} / \mathrm{ml}$ (pyraclostrobin).

Of the 54 isolates tested at discriminatory doses of azoxystrobin and pyraclostrobin at 100 and $10 \mu \mathrm{g} / \mathrm{ml}$, respectively, 43 isolates were inhibited $<50 \%$ when compared with the control treatment. Mycelial growth of the other 11 C. acutatum isolates was inhibited. Of the 11 isolates that were inhibited, 2 had not been exposed to strobilurin fungicides, whereas the other 9 isolates (collected in 2013 to 2014) had been exposed to strobilurin fungicides.

Isolates showing mycelial growth inhibition at azoxystrobin and pyraclostrobin concentrations up to 3 and $0.11 \mu \mathrm{g} / \mathrm{ml}$, respectively, were considered QoI sensitive. Isolates that were not inhibited at the aforementioned concentrations but were inhibited when exposed to azoxsytrobin at $100 \mu \mathrm{g} / \mathrm{ml}$ and pyraclostrobin at $10 \mu \mathrm{g} / \mathrm{ml}$ were considered moderately resistant. Isolates that had $\mathrm{EC}_{50}$ values greater than 100 and $10 \mu \mathrm{g} / \mathrm{ml}$ for azoxystrobin and pyraclostrobin, respectively, were designated completely resistant. All isolates collected from fruit and crown tissues during the 2013-14 and 2014-15 seasons were resistant. In all, 14 of the 19 root isolates collected during the 2013-14 season and all of the root isolates collected during the 2014-15 season were also resistant. In addition, of the 48 resistant isolates, the majority $(n=33)$ of them came from transplants obtained from three of the six nurseries sampled (data not shown).

Spore germination and germ tube elongation. C. acutatum spore germination was not significantly affected by the addition of SHAM at $100 \mu \mathrm{g} / \mathrm{ml}$ to fungicide-amended media. The percentage of germinated conidia ranged from 46 to $71 \%$ on the control plates without the addition of SHAM and from 54 to $78 \%$ with the addition of SHAM. Germination of $C$. acutatum spores was not inhibited by azoxystrobin at concentrations up to $100 \mu \mathrm{g} / \mathrm{ml}$ but growth rate of germ tubes was inhibited compared with the control treatments. Of the 12 isolates tested, 7 had $\mathrm{EC}_{50}$ values higher than $3 \mu \mathrm{g} / \mathrm{ml}$ for azoxystrobin and $0.110 \mu \mathrm{g} / \mathrm{ml}$ for pyraclostrobin and were considered resistant to both fungicides. The other five isolates had $\mathrm{EC}_{50}$ values that ranged from 0.08 to $1.2 \mu \mathrm{g} / \mathrm{ml}$ for azoxystrobin and from 0.009 to 0.07 $\mu \mathrm{g} / \mathrm{ml}$ for pyraclostrobin and were considered sensitive, including baseline isolate 95-61C (Fig. 1). The lowest germ tube elongation mean $\mathrm{EC}_{50}$ values for both QoI were observed for isolate 14-57 collected from petiole tissue, whereas the highest $\mathrm{EC}_{50}$ value among the sensitive isolates was from fruit isolate 13-73 collected in 2013. Mycelial growth and germ tube elongation results were similar for the SHAM-amended media. $\mathrm{EC}_{50}$ for mycelial growth and germ tube elongation were not significantly different for each of the 12 isolates $(P=0.4201)$.

Detached-fruit assay. Field rates of commercial formulations of azoxystrobin and pyraclostrobin failed to control anthracnose on fruit inoculated with QoI-resistant C. acutatum isolates. In the first trial, disease incidence on fruit treated with azoxystrobin and pyraclostrobin ranged from 43.7 to $87.5 \%$ and from 56.2 to $100 \%$, respectively. Disease incidence in the second trial ranged from 25 to $62.5 \%$ (azoxystrobin) and from 31.2 to $100 \%$ (pyraclostrobin) (Table 2). Fruit inoculated with sensitive isolates were controlled by field rates. AFR symptoms were observed in the nontreated control when inoculated with 9 of the 12 tested isolates. Interestingly, disease incidence and severity was null or low (6.25\% incidence and $1.2 \%$ severity) on fruit inoculated with the three chromogenic $C$. acutatum isolates (13-10, 13-73, and 13-486).

Analysis of $c y t b$ gene sequences from sensitive and resistant C. acutatum isolates. Nucleotide sequencing of part of the $c y t b$ gene of 18 C. acutatum isolates revealed two substitutions from phenylalanine $(\mathrm{F})$ by leucine $(\mathrm{L})$ at codon 129 and from glycine $(\mathrm{G})$ to alanine (A) at codon 143 in QoI-resistant isolates. Of the 11 isolates sequenced, 2 isolates showed the F129 L mutation (13-494 and 14141) whereas 7 exhibited the G143A mutation (Fig. 2). These isolates were all collected in 2013 or 2014 . No mutation was observed in any of the QoI-sensitive isolates.

\section{Discussion}

In Florida strawberry fields, azoxystrobin and pyraclostrobin are frequently used to control $C$. acutatum. In this study, we observed a decrease in sensitivity and a shift toward resistance of $C$. acutatum isolates collected in 2013 and 2014 from isolates collected previously. To our knowledge, this is the first report of QoI resistance in C. acutatum on strawberry or any other crop affected by this pathogen.

All isolates collected from 1994 to 2011 exhibited sensitivity to azoxystrobin and pyraclostrobin. Mean $\mathrm{EC}_{50}$ values of isolates not exposed to QoI fungicides based upon mycelial growth were 0.30 and $0.014 \mu \mathrm{g} / \mathrm{ml}$ for azoxystrobin and pyraclostrobin, respectively. Similar findings have been reported for isolates with no previous QoI exposure in Alternaria spp. on pistachio, C. graminicola on turf, and C. acutatum on citrus (Avila-Adame et al. 2003; Ma et al. 2003; Mondal et al. 2005). For isolates collected after the release of QoI fungicides until 2011, mean $\mathrm{EC}_{50}$ values were $0.15 \mu \mathrm{g} / \mathrm{ml}$ for azoxystrobin and $0.011 \mu \mathrm{g} / \mathrm{ml}$ for pyraclostrobin. $\mathrm{EC}_{50}$ values determined upon mycelial growth and germ tube elongation assays for sensitive isolates of C. acutatum were lower for pyraclostrobin than azoxystrobin. This difference has been observed for many other pathogens such as Guignardia citricarpa, Alternaria alternata, Diaporthe citri, Mycosphaerella citri, and C. acutatum from citrus (Hincapie et al. 2014; Mondal et al. 2005).

A majority of C. acutatum isolates collected from the 2012-13, 2013-14, and 2014-15 seasons were not inhibited by pyraclostrobin and azoxystrobin at 0.110 and $3 \mu \mathrm{g} / \mathrm{ml}$, respectively, and were considered resistant. When exposed to concentrations of pyraclostrobin at up to $10 \mu \mathrm{g} / \mathrm{ml}$ and azoxystrobin at up to $100 \mu \mathrm{g} / \mathrm{ml}$, most but not all of the isolates were still not inhibited. Mycelial growth of $C$. acutatum isolates with $\mathrm{EC}_{50}$ values between 3 and $100 \mu \mathrm{g} / \mathrm{ml}$ for azoxystrobin and 0.110 and $10 \mu \mathrm{g} / \mathrm{ml}$ for pyraclostrobin were considered moderately resistant; and those with $\mathrm{EC}_{50}$ values higher than 100 and $10 \mu \mathrm{g} / \mathrm{ml}$ for azoxystrobin and pyraclostrobin, respectively, were considered completely resistant. A similar level of resistance was found in a study testing field azoxystrobin-resistant isolates of $B$. cinerea; of 184 isolates, 7 grew on media amended with azoxystrobin at 50 or $100 \mathrm{mg} /$ liter (Jiang et al. 2009). More recently, $86.5 \%$ of B. cinerea isolates from Florida had a mean $\mathrm{EC}_{50}$ value for pyraclostrobin higher than $347 \mu \mathrm{g} / \mathrm{ml}$ based upon mycelial growth using the spiral gradient method (Amiri et al. 2013). Interestingly, 
B. cinerea isolates tested by Amiri et al. (2013) were collected from the same region from which our tested $C$. acutatum isolates were collected.

Although QoI fungicides act by blocking the pathway required for fungal ATP production, disrupting energy supply, many plantpathogenic fungi avoid the toxic effects of RI fungicides by developing an alternative respiration pathway in vitro. Thus, the addition of SHAM into the fungicide-amended media is to prevent a falsepositive result when evaluating the sensitivity of a certain fungi to RI fungicides (Wood and Hollomon 2003). In our study, the addition of SHAM to fungicide-amended media had no effect on C. acutatum spore germination and germ tube elongation. Our findings concur with studies evaluating sensitive $C$. acutatum isolates of citrus (Mondal et al. 2005) and $C$. coccodes of potato (Aqeel 2007) and resistant $C$. graminicola isolates from turf (Avila-Adame et al. 2003). These studies found that SHAM had no effect on the activity of strobilurin fungicides and concluded that some Colletotrichum spp. do not develop the alternative respiration pathway and cannot overcome QoI sensitivity (Aqeel 2007; Avila-Adame et al. 2003; Mondal et al. 2005). Likewise, Hincapie et al. (2014) observed no significant increase in sensitivity in mycelial growth and spore germination of G. citricarpa exposed to azoxystrobin + SHAM. Because SHAM had no effect on spore germination and mycelial growth of $C$. acutatum obtained from strawberry and citrus, we suggest that SHAM may not be necessary when evaluating QoI sensitivity in C. acutatum.

Interestingly, spore germination of sensitive $C$. acutatum isolates was not inhibited by azoxystrobin even though the growth rate was reduced. Spore germination of $C$. acutatum from citrus was also not highly inhibited by benomyl (Peres et al. 2004). However, germ tubes of sensitive isolates had reduced elongation on azoxystrobin- and pyraclostrobin-amended media, whereas germ tube length of resistant isolates was similar to the control. Our results suggest that either C. acutatum germ tube elongation or mycelial growth assays are adequate to evaluate QoI sensitivity but spore germination assays are inadequate.
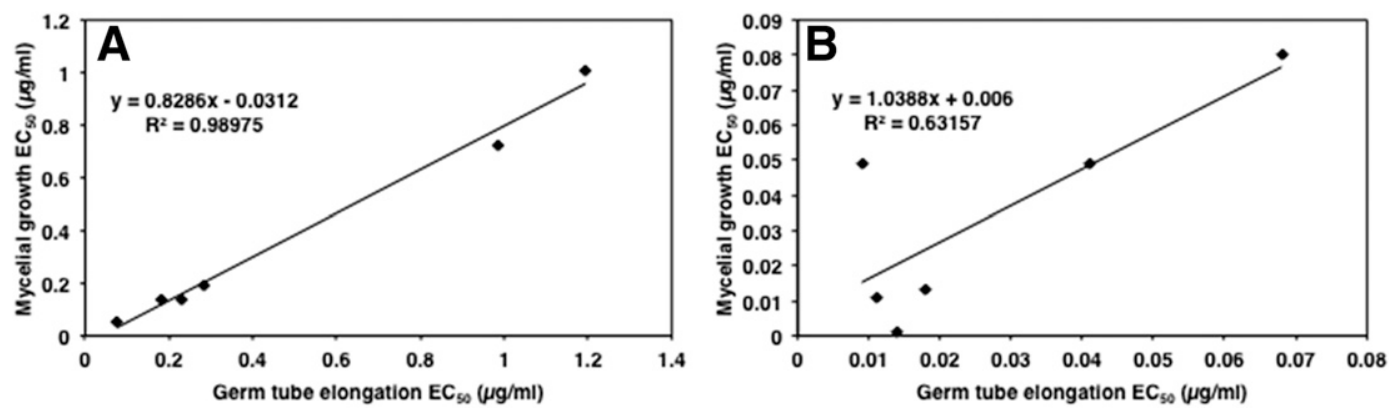

Fig. 1. Relationship between effective doses of $\mathbf{A}$, azoxystrobin and $\mathbf{B}$, pyraclostrobin to reduce $50 \%$ ( $\left.E C_{50}\right)$ of germ tube elongation (GTE) and mycelial growth (MG) for six sensitive isolates of Colletotrichum acutatum from strawberry.

Table 2. Efficacy of azoxystrobin and pyraclostrobin in controlling anthracnose fruit rot on strawberry fruit inoculated with Colletotrichum acutatum isolates with different levels of sensitivity

\begin{tabular}{|c|c|c|c|c|c|c|}
\hline \multirow[b]{3}{*}{ Fungicide, isolate } & \multirow[b]{3}{*}{$\mathrm{EC}_{50}(\mu \mathrm{g} / \mathrm{ml})^{\mathbf{a}}$} & \multirow[b]{3}{*}{ Phenotype $^{\text {b }}$} & \multicolumn{4}{|c|}{ Anthracnose fruit rot (\%) } \\
\hline & & & \multicolumn{2}{|c|}{ Experiment 1} & \multicolumn{2}{|c|}{ Experiment 2} \\
\hline & & & Incidence & Severity & Incidence & Severity \\
\hline \multicolumn{7}{|l|}{ Azoxystrobin } \\
\hline $95-61$ & 0.140 & $\mathrm{~S}$ & 0 & 0 & 0 & 0 \\
\hline $03-2$ & 0.196 & $\mathrm{~S}$ & 0 & 0 & 0 & 0 \\
\hline $08-11$ & 0.134 & $\mathrm{~S}$ & 0 & 0 & 0 & 0 \\
\hline $13-10$ & 0.419 & S & 0 & 0 & 0 & 0 \\
\hline $13-73$ & 1.010 & $S$ & 0 & 0 & 0 & 0 \\
\hline $13-483$ & 0.150 & S & 0 & 0 & 0 & 0 \\
\hline $13-486$ & 1.625 & S & 0 & 0 & 0 & 0 \\
\hline $14-57$ & 0.055 & $S$ & 0 & 0 & 0 & 0 \\
\hline $13-139$ & $>3$ & $\mathrm{R}$ & 43.7 & 3.1 & 25 & 3.2 \\
\hline $13-459$ & $>3$ & $\mathrm{R}$ & 87.5 & 11.2 & 43.7 & 5.6 \\
\hline $13-488$ & $>3$ & $\mathrm{R}$ & 75 & 6.9 & 37.5 & 5.2 \\
\hline $14-58$ & $>3$ & $\mathrm{R}$ & 68.7 & 6.8 & 62.5 & 4.8 \\
\hline \multicolumn{7}{|l|}{ Pyraclostrobin } \\
\hline $95-61$ & 0.014 & S & 0 & 0 & 0 & 0 \\
\hline 03-2 & 0.011 & S & 0 & 0 & 0 & 0 \\
\hline $08-11$ & 0.013 & S & 0 & 0 & 0 & 0 \\
\hline $13-10$ & 0.035 & $S$ & 0 & 0 & 0 & 0 \\
\hline $13-73$ & 0.081 & S & 0 & 0 & 25 & 1.2 \\
\hline $13-483$ & 0.037 & S & 0 & 0 & 0 & 0 \\
\hline $13-486$ & 0.066 & S & 0 & 0 & 0 & 0 \\
\hline $14-57$ & 0.041 & $S$ & 0 & 0 & 0 & 0 \\
\hline $13-139$ & $>0.110$ & $\mathrm{R}$ & 56.2 & 4.1 & 31.2 & 5.3 \\
\hline $13-459$ & $>0.110$ & $\mathrm{R}$ & 68.7 & 7.8 & 62.5 & 5.6 \\
\hline $13-488$ & $>0.110$ & $\mathrm{R}$ & 62.5 & 4.5 & 37.5 & 3.7 \\
\hline $14-58$ & $>0.110$ & $\mathrm{R}$ & 100 & 9 & 100 & 9.8 \\
\hline
\end{tabular}

${ }^{\mathrm{a}} \mathrm{EC}_{50}=$ effective concentration where growth was reduced by $50 \%$.

b $\mathrm{S}=$ sensitive $C$. acutatum isolates. Mycelial growth $\mathrm{EC}_{50}$ values were $<3 \mu \mathrm{g} / \mathrm{ml}$ and $<0.110 \mu \mathrm{g} / \mathrm{ml}$ for azoxystrobin and pyraclostrobin, respectively. $\mathrm{R}=$ resistant $C$. acutatum isolates. Mycelial growth $\mathrm{EC}_{50}$ values were $\geq 3 \mu \mathrm{g} / \mathrm{ml}$ and $\geq 0.110 \mu \mathrm{g} / \mathrm{ml}$ for azoxystrobin and pyraclostrobin, respectively. 
Florida strawberry growers have considered QoI fungicides a powerful tool against AFR and ARN and have made repeated use of them since their release (Mertely and Peres 2012a,b; Turechek et al. 2006). In our study, field rates of azoxystrobin and pyraclostrobin failed to control AFR on strawberry fruit inoculated with resistant $C$. acutatum isolates but successfully controlled sensitive isolates. Control failures of ARN were observed by some growers in Florida during the 2013-14 season and were confirmed in an experiment where infected transplants were dipped in azoxystrobin (Mertely and Peres 2014). Disease control failures of azoxystrobin have been reported with C. graminicola and B. cinerea (Avila-Adame et al. 2003; Jiang et al. 2009). Avila-Adame et al. (2003) observed that, on turf previously exposed to frequent azoxystrobin applications, the same fungicide failed to control resistant isolates of $C$. graminiola, and Jiang et al. (2009) reported normal disease development on cucumber leaves treated with azoxystrobin at $100 \mu \mathrm{g} / \mathrm{ml}$ and inoculated with resistant $B$. cinerea isolates.

In our study, resistance to azoxystrobin and pyraclostrobin in C. acutatum was conferred by two point mutations in the $c y t b$ gene. For the $18 \mathrm{C}$. acutatum isolates sequenced, cytb sequences indicated the presence of the F129L and G143A amino acid substitutions. The occurrence of the F129L point mutation has been linked to moderate levels of resistance and disease control can be achieved, but only with higher fungicide concentrations than that used to control sensitive isolates (Bartlett et al. 2002; Pasche et al. 2004; Sierotzki et al. 2007). Based upon mycelial growth, the two $C$. acutatum isolates containing the F129L mutation (13-494 and 14-141) had $\mathrm{EC}_{50}$ values of 36.96 and $31.41 \mu \mathrm{g} / \mathrm{ml}$ for azoxystrobin and 1.22 and 2.46 $\mu \mathrm{g} / \mathrm{ml}$ for pyraclostrobin, respectively. These values ranged between the $\mathrm{EC}_{50}$ values of sensitive isolates and isolates having the G143A mutation. The occurrence of this mutation has been documented in studies with strobilurin-resistant isolates of Pyricularia grisea from ryegrass turf (Kim et al. 2003) and A. solani from potato (Pasche and Gudmestad 2008) but no information on C. acutatum has yet been reported. The glycine-to-alanine exchange at position 143 was found in the other nine QoI-resistant C. acutatum isolates. The $\mathrm{EC}_{50}$ values of these isolates for pyraclostrobin and azoxystrobin are higher than 10 and $100 \mu \mathrm{g} / \mathrm{ml}$, respectively. This suggests that these isolates are completely resistant to both QoI fungicides and cannot be controlled even at high concentrations. The G143A point mutation has been previously reported as the main mutation involved in practical resistance of many fungal pathogens to QoI-fungicides (Fernández-Ortuño et al. 2012; Lesniak et al. 2011; Ma et al. 2003; Miles et al. 2012),

\begin{tabular}{|c|c|}
\hline (S) & AMI \\
\hline הנצניו & GQMSL-GATVITN \\
\hline (S) & SIG-F \\
\hline & MGIG-FLGY \\
\hline & AMMGIG-FLGY \\
\hline & AMMGIG-LLC \\
\hline & $\mathrm{S}-\overrightarrow{\mathrm{F}}$ \\
\hline & Al \\
\hline & Al \\
\hline & 52 \\
\hline & 53 \\
\hline & I 51 \\
\hline & 52 \\
\hline & 52 \\
\hline & 49 \\
\hline & 51 \\
\hline & 51 \\
\hline & {$[51$} \\
\hline
\end{tabular}

Fig. 2. Amino acid sequence alignment of the partial cytochrome $b$ gene for Colletotrichum acutatum isolates from strawberry. A mutation at codon 129 from phenylalanine to leucine was observed for moderately resistant isolates 13-494 and 14-141. A mutation at codon 143 from glycine to alanine was observed for completely resistant isolates 13-466, 13-468, 13-471, 13-472, 13-473, 13-475, 13479, 14-61, and 14-87. Isolates 98-1, 02-153, 02-159, 02-160, 02-179, 13-73, and 14-57 were sensitive and had no point mutation. including C. graminicola (Avila-Adame et al. 2003). Similar to our results, Ma et al. (2003) reported the presence of the G143A point mutation in isolates of Alternaria spp. from pistachio with $\mathrm{EC}_{50}$ values for azoxystrobin higher than $100 \mu \mathrm{g} / \mathrm{ml}$, based upon conidial germination. Likewise, in strawberry fields previously sprayed with pyraclostrobin, Fernández-Ortuño et al. (2012) identified a high frequency of $B$. cinerea isolates that had the G143A substitution.

Resistance in strawberry isolates of $C$. acutatum from Florida to QoI fungicides is reported herein for the first time. We found that AFR and ARN control failures observed during the 2013-14 season were due to QoI resistance caused by two point mutations in the cytb gene in QoI-resistant isolates of C. acutatum. It is likely that resistant C. acutatum populations were carried on transplants that originated from strawberry production nurseries because the majority of the resistant isolates were recovered from infected roots and crowns soon after planting. The fact that the majority of resistant isolates originated from only three nurseries leads us to believe that resistance is still not widespread and it is linked to plant source. Our findings should have significant implications for disease management because azoxystrobin and pyraclostrobin have been the main single-site fungicides used to control AFR and ARN. Shifts toward resistance to QoI and other single-site fungicides have also been reported for $B$. cinerea, resulting in limited chemical resources available for control of the two major diseases affecting strawberry in Florida (Amiri et al. 2013). QoI resistance in C. acutatum appears to be limited to Florida and not yet widespread; however, this situation warrants immediate changes in AFR and ARN management strategies to limit selection and prevent spread of QoI-resistant populations. Furthermore, management strategies should aim to integrate disease management across the nursery and fruit production systems, and research on alternative nonchemical suppressive methods is needed.

\section{Acknowledgments}

This research is based upon work that was supported by the National Institute of Food and Agriculture, United States Department of Agriculture under award number 2010-51181-21113. We thank E. Zuchelli and L. Maurer for technical assistance.

\section{Literature Cited}

Amiri, A., Heath, S. M., and Peres, N. A. 2013. Phenotypic characterization of multifungicide resistance in Botrytis cinerea isolates from strawberry fields in Florida. Plant Dis. 97:393-401.

Aqeel, A. M. 2007. Response of Colletotrichum coccodes to QoI fungicide in vitro. Plant Pathol. J. 4:283-290.

Avila-Adame, C., Olaya, G., and Köller, W. 2003. Characterization of Colletotrichum graminicola isolates resistant to strobilurin-related QoI fungicides. Plant Dis. 87: 1426-1432.

Bartlett, D. W., Clough, J. M., Godwin, J. R., Hall, A. A., Hamer, M., and ParrDobrzanski, B. 2002. The strobilurin fungicides. Pest Manage. Sci. 58:649-662.

Daugovish, O., Su, H., and Gubler, W. D. 2009. Preplant fungicide dips of strawberry transplants to control anthracnose caused by Colletotrichum acutatum in California. HortTechology 19:317-323.

Duan, Y., Liu, S., Ge, C., Feng, X., Chen, C., and Zhou, M. 2012. In vitro inhibition of Sclerotinia sclerotiorum by mixtures of azoxystrobin, SHAM, and thiram. Pestic. Biochem. Physiol. 103:101-107.

Fernández-Ortuño, D., Chen, F., and Schnabel, G. 2012. Resistance to pyraclostrobin and boscalid in Botrytis cinerea isolates from strawberry fields in the Carolinas. Plant Dis. 96:1198-1203.

Förster, H., Kanetis, L., and Adaskaveg, J. E. 2004. Spiral gradient dilution, a rapid method for determining growth responses and 50\% effective concentration values in fungus-fungicide interactions. Phytopathology 94:163-170.

Freeman, S., and Katan, T. 1997. Identification of Colletotrichum species responsible for anthracnose and root necrosis of strawberry in Israel. Phytopathology 87: 516-521.

FRAC. 2016. FRAC code list 2016: Fungicides sorted by mode of action (including FRAC code numbering). Online publication available at http:// www.frac.info

Gisi, U., Sierotzki, H., Cook, A., and McCaffery, A. 2002. Mechanisms influencing the evolution of resistance to Qo inhibitor fungicides. Pest Manage. Sci. 58:859-867.

Hincapie, M., Wang, N.-Y., Peres, N. A., and Dewdney, M. M. 2014. Baseline sensitivity of Guignardia citricarpa isolates from Florida to azoxystrobin and pyraclostrobin. Plant Dis. 98:780-789.

Howard, M. H., Maas, J. L., Chandler, C. K., and Albregts, E. E. 1992 Anthracnose of strawberry caused by the Colletotrichum complex in Florida Plant Dis. 76:976-981. 
Ishii, H., Fraaije, B. A., Sugiyama, T., Noguchi, K., Nishimura, K., Takeda, T., Amano, T., and Hollomon, D. W. 2001. Occurrence and molecular characterization of strobilurin resistance in cucumber powdery mildew and downy mildew. Phytopathology 91:1166-1171.

Jiang, J., Ding, L., Michailides, T., Li, H., and Ma, Z. 2009. Molecular characterization of field azoxystrobin-resistant isolates of Botrytis cinerea. Pestic. Biochem. Physiol. 93:72-76.

Kim, Y. S., Dixon, E. W., Vincelli, P., and Farman, M. L. 2003. Field resistance to strobilurin (QoI) fungicides in Pyricularia grisea caused by mutations in the mitochondrial cytochrome b gene. Phytopathology 93:891-900.

Leandro, L. F. S., Gleason, M. L., Nutter, F. W., Jr., Wegulo, S. N., and Dixon, P. M. 2001. Germination and sporulation of Colletotrichum acutatum on symptomless strawberry leaves. Phytopathology 91:659-664.

Legard, D. E., MacKenzie, S. J., Mertely, J. C., and Chandler, C. K. 2003. Evaluation of fungicides to control anthracnose fruit rot of strawberry, 20012002. Online publication. Fungic. Nematicide Tests 58:SMF009.

Lesniak, K. E., Proffer, T. J., Beckerman, J. L., and Sundin, G. W. 2011. Occurrence of QoI resistance and detection of the G143A mutation in Michigan populations of Venturia inaequalis. Plant Dis. 95:927-934.

Ma, Z., Felts, D., and Michailides, T. 2003. Resistance to azoxystrobin in Alternaria isolates from pistachio in California. Pestic. Biochem. Physiol. 77:66-74.

Maas, J. L., ed. 1998. Compendium of Strawberry Diseases. American Phytopathological Society, St. Paul, MN.

MacKenzie, S. J., and Peres, N. A. 2012. Use of leaf wetness and temperature to time fungicide applications to control anthracnose fruit rot of strawberry in Florida. Plant Dis. 96:522-528.

Mertely, J. C., and Peres, N. A. 2012a. Anthracnose fruit rot of strawberry. Publ. No. PP-207. University of Florida, IFAS, EDIS, Gainesville.

Mertely, J. C., and Peres, N. A. 2012b. Root necrosis of strawberries caused by Colletotrichum acutatum. Publ. No. PP-211. University of Florida, IFAS, EDIS, Gainesville.

Mertely, J. C., and Peres, N. A. 2014. Control of Colletotrichum acutatum on infected strawberry transplants. (Abstr.) Phytopathology 104:S3.80.

Mertely, J. C., Seijo, T. E., and Peres, N. A. 2010. Effect of pre- and post-plant fungicide and fertilizer treatments on infection by Colletotrichum acutatum, plant survival, and yield of annual strawberry in Florida. Online publication. Plant Health Prog. doi:10.1094/PHP-2010-0125-01-RS

Miles, L. A., Miles, T. D., Kirk, W. W., and Schilder, A. M. C. 2012. Strobilurin (QoI) resistance in populations of Erysiphe necator on grapes in Michigan. Plant Dis. 96:1621-1628.
Mondal, S. N., Bhatia, A., Shilts, T., and Timmer, L. W. 2005. Baseline sensitivities of fungal pathogens of fruit and foliage of citrus to azoxystrobin, pyraclostrobin, and fenbuconazole. Plant Dis. 89:1186-1194.

Pasche, J. S., and Gudmestad, N. C. 2008. Prevalence, competitive fitness and impact of the F129L mutation in Alternaria solani from the United States. Crop Prot. 27:427-435.

Pasche, J. S., Wharam, C. M., and Gudmestad, N. C. 2004. Shift in sensitivity of Alternaria solani in response to QoI fungicides. Plant Dis. 88:181-187.

Peres, N. A. 2015. 2015 Florida Plant Disease Management Guide: Strawberry. Publ. No. PDMG-V3-50. University of Florida, IFAS, EDIS. Gainesville.

Peres, N. A., Seijo, T. E., and Moyer, C. 2009. Baseline sensitivities of isolates of Colletotrichum acutatum to strobilurin (QoI) fungicides. (Abstr.) Phytopathology 99:S101.

Peres, N. A., and MacKenzie, S. J. 2013. Colletotrichum crown rot (anthracnose crown rot) of strawberries. Publ. No. PP-238. University of Florida, IFAS, EDIS, Gainesville.

Peres, N. A., Timmer, L. W., Adaskaveg, J. E., and Correl, J. C. 2005. Lifestyles of Colletotrichum acutatum. Plant Dis. 89:784-796.

Peres, N. A. R., Souza, N. L., Peever, T. L., and Timmer, L. W. 2004. Benomyl sensitivity of isolates of Colletotrichum acutatum and C. gloeosporioides from citrus. Plant Dis. 88:125-130.

Sauter, H., Steglich, W., and Anke, T. 1999. Strobilurins: Evolution of a new class of active substances. Angew. Chem. Int. Ed. 38:1328-1349.

Sierotzki, H., Frey, R., Wullschleger, J., Palmero, S., Karlin, S., Godwin, J., and Gisi, U. 2007. Cytochrome b gene sequence and structure of Pyrenophora teres and P. tritici-repentis and implications for QoI resistance. Pest Manage. Sci. 63:225-233.

Turechek, W. W., Peres, N. A., and Werner, N. A. 2006. Pre- and post-infection activity of pyraclostrobin for control of anthracnose fruit rot of strawberry caused by Colletotrichum acutatum. Plant Dis. 90:862-868.

Ureña-Padilla, A. R., Mitchell, D. J., and Legard, D. E. 2001. Oversummer survival of inoculum for Colletotrichum crown rot in buried strawberry crown tissue. Plant Dis. 85:750-754.

Wilson, L. L., Madden, L. V., and Ellis, M. A. 1990. Influence of temperature and wetness duration on infection of immature and mature strawberry fruit by Colletotrichum acutatum. Phytopathology 80:111-116.

Wood, P. M., and Hollomon, D. W. 2003. A critical evaluation of the role of alternative oxidase in the performance of strobilurin and related fungicides acting at the Qo site of complex III. Pest Manage. Sci. 59:499-511.

Ypema, H. L., and Gold, R. E. 1999. Kresoxim-methyl. Modification of a natural occurring compound to produce a new fungicide. Plant Dis. 83:4-19. 